\title{
ЕКСПЕРИМЕНТАЛЬНЕ ДОСЛІДЖЕННЯ ДИНАМІКИ РУХУ ШТОКА ГІДРОЦИЛІНДРА ПІДЙОМУ ШАРНІРНО-ЗЧЛЕНОВАНОЇ СТРІЛОВОЇ СИСТЕМИ КРАНА-МАНІПУЛЯТОРА 3 ГІДРОПРИВОДОМ
}

АНОТАЦІЯ. Розглянута експериментальна установка крана-маніпулятора з гідроприводом та вимірювально-реєструюче обладнання для проведення досліджень з визначенням динамічних навантажень на їі робочому обладнанні. Представлено результати експериментальних досліджень.

Ключові слова: маніпулятор, експеримент, динаміка маніпулятора.

АННОТАЦИЯ. Рассмотрена экспериментальная установка крана-манипулятора с гидроприводом и измерительно-регистрирующее оборудование для исследований с определением динамических нагрузок на ее рабочем оборудовании. Приведены результаты экспериментальных исследований.

Ключевые слова: манипулятор, эксперимент, динамика манипулятора.

SUMMARY. The experimental setting of faucet-manipulator is considered fluid-operated and instrumentation recording equipment for bringing researches over from determination of the dynamic loadings on its working equipment. The results of experimental researches are presented.

Key words: manipulator, experiment, dynamics of manipulator.

\section{Постановка проблеми}

Одним із розповсюджених механізмів будівельних машин є гідрофікований вантажний кран-маніпулятор. Гідрофіковані крани-маніпулятори на транспортних засобах досить широко застосовуються в будівництві для виконання вантажних та монтажних робіт. Використання кранів-маніпуляторів дозволяє скоротити час простою автотранспорту та кількість автотранспортних засобів.

Значний вплив на ефективність будівництва відіграє підвищення надійності кранівманіпуляторів з гідроприводом, які використовують на транспортних засобах. Серед напрямків, що сприяють підвищенню надійності слід відмітити зниження динамічних навантажень [1].

Однією $з$ причин виникнення динамічних навантажень в кранах-маніпуляторах $\epsilon$ несталий характер режимів їх роботи, обумовлений частим його вмиканням. Несталий характер роботи крана-маніпулятора характеризується високими амплітудами коливань тиску в гідроприводі та прискореннями привідних механізмів. Це викликає нерівномірний рух вантажу, виникають додаткові навантаження на силові елементи та систему приводу, створюються незручності при експлуатації.
Отже постає задача дослідження динамічних навантажень в робочому обладнанні крана-маніпулятора під час зміни вильоту вантажу та розробці режимів руху кранаманіпулятора за яких динамічні навантаження будуть мінімальні.

Аналіз останніх досліджень і публікацій

Існують способи зі зменшення динамічних навантажень в робочому обладнанні кранів-маніпуляторів та усунення коливань вантажу при їх переміщенні [2]. Одним 3 розповсюджених серед них $є$ застосування слідкуючих систем [3], проте вони є складними динамічними ланками, а тому їх використання пов'язано зі значними витратами на виготовлення. Як пристрої, що дозволяють знижувати динамічні навантаження в ланках та приводі кранаманіпулятора, також застосовують автоматично регульовані гальмівні пристрої [4], які встановлюють в гідромагістралі системи гідроприводу крана-маніпулятора. Проте без чітко визначеного режиму керування такими пристроями можливі розриви потоку робочої рідини в магістралях гідроприводу [5].

В наш час актуальними є задачі зниження динаміки роботи крана-маніпулятора, пов'язані 3 оптимальним керуванням [6]. На основі оптимазіційних задач визнача- 
ються режими робота крана-маніпулятора 3 мінімальними динамічними навантаженнями та коливаннями вантажу, на підставі яких виконують програмне оптимальне керування. В роботах $[7,8]$ розглянуто та визначено оптимальні режими руху стрілової системи крана-маніпулятора тільки за однієї рухомої координати без урахування коливань вантажу, але 3 урахуванням його маятникових коливань. В дослідженні [8] приведено теоретичне визначення динамічних привідних сил за оптимальних режимів роботи крана-маніпулятора. Проте ефективність синтезу оптимальних режимів роботи стрілової системи крана-маніпулятора вимагає проведення експериментальних досліджень динаміки його роботи.

Метою даної роботи $\epsilon$ експериментальне визначення динамічних навантажень в елементах шарнірно-зчленованої стрілової системи крана-маніпулятора при зміні вильоту вантажу за роботи лише гідроциліндра підйому за неоптимального та оптимального режимів його роботи.

\section{Виклад основного матеріалу}

Для проведення експериментальних досліджень було розроблено фізичну модель крана-маніпулятора та визначені коефіцієнти ії пропорційності до натурної установки [9]. На рис.1 зображено виготовлену експериментальну установку крана-маніпулятора 3 гідроприводом, яка була спроектована на основі розробленої його фізичної моделі. Експериментальна установка, що розглядається, складається 3 бази, на якій встановлена шарнірно-зчленована стріла 3 привідними гідроциліндрами, гідростанція та механізми системи керування.

До складу гідростанції входять: електродвигун трифазного струму АИМ80В4 потужністю $1,5 \kappa$ Вт та частотою обертання 1000 об/хв.; гідронасос НШ10У-3; гідробак 3 фільтром та електрообладнання. Привід гідронасоса здійснюється через клинопасову передачу.

Керування потоком робочої рідини в системі гідроприводу виготовленої установки крана-маніпулятора виконуються універсальним розподільником Р80-3/1-444.

При проведенні експериментальних досліджень зі встановлення закономірностей руху установки крана-маніпулятора на оптимальних та неоптимальних режимах роботи системи, необхідно створити керуючу дію на виконавчих механізмах стрілової системи експериментальної установки. Для створення оптимальних режимів пуску i гальмування експериментальної установки крана-маніпулятора у процесі зміни вильоту вантажу в його систему гідроприводу вводиться апаратура, яка дає змогу здійснити плавну зміну потоку робочої рідини. Пристроєм керування, що буде виконувати керуючу дію на привідний механізм експериментальної установки крана-маніпулятора, буде гідророзподільник його бортової системи з конструктивними змінами.

В гідророзподільнику бортової гідросис-

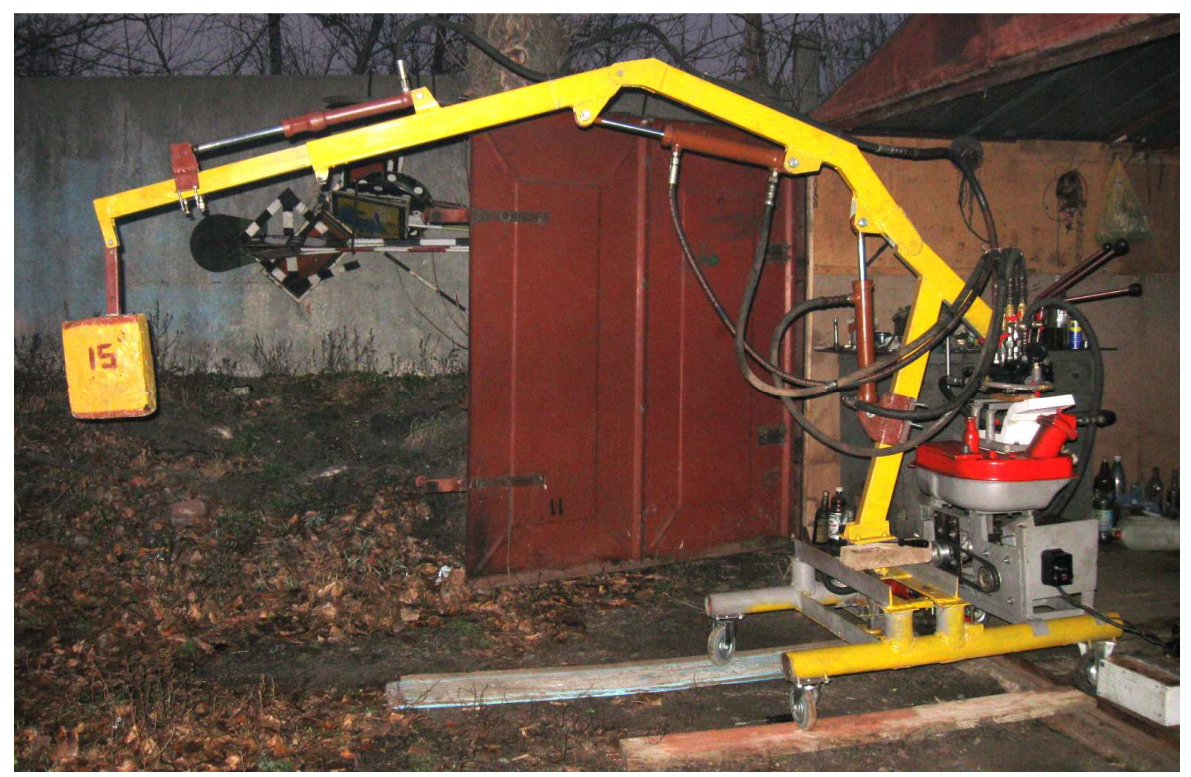

Рис. 1. Експериментальна установка крана-маніпулятора 3 гідроприводом 
теми експериментальної установки кранаманіпулятора було змінено конструкцію одного із золотників. На торцях робочих поверхонь циліндричного золотника були нарізані дросельні щілини згідно розрахунку оптимального режиму роботи експериментальної установки крана-маніпулятора (рис.2).

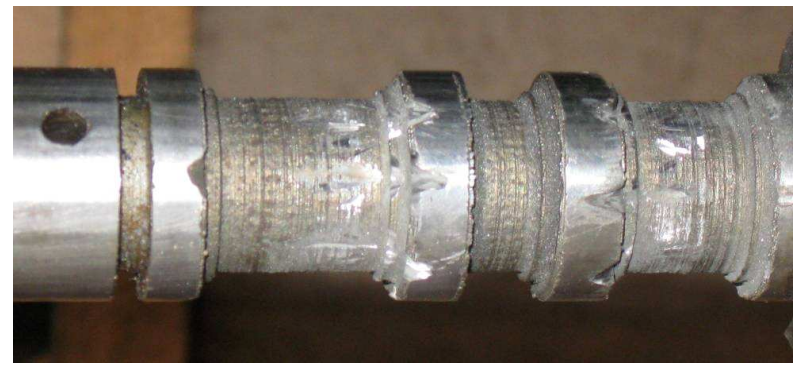

Рис. 2. Дросельні щілини на робочих поверхнях золотника

Характеристики руху стрілової системи експериментальної установки кранаманіпулятора визначалися з використанням електронного обладнання [9].

Для визначення прискорення штока підйомного привідного гідроциліндра експериментальної установки крана-маніпулятора, в місці закріплення штока - на його шарнірі, встановлено монтажну планку для датчиків прискорення. Монтажна планка виконана таким чином, що дозволяє закріплювати на ній одночасно два датчики у взаємно перпендикулярних площинах (рис.3).



Рис. 3. Розміщення акселерометрів на штоку підйомного гідроциліндра

Фіксування прискорення штока привідного гідроциліндра експериментальної установки крана-маніпулятора виконувало- ся за допомогою двох однокоординатних п'єзоелектричних датчиків вібрації ВС110 (акселерометрів).

Датчики мають п'єзоелемент, що реагує на переміщення його корпусу та створює, тим самим, перепад напруги на своїх виходах.

Тиск у напірній (поршневій) порожнині привідного гідроциліндра вимірювався за допомогою п“єзоелектричного датчика тиску ДМП-100.

Датчик тиску через з'єднувальну арматуру був вмонтований в нагнітальний рукав високого тиску привідного гідроциліндра підйому стріли (рис.4).



Рис. 4. Датчик тиску

Для зчитування сигналів 3 датчиків застосовувався підсилювач-перетворювач SPIDER 8-FO5254 та персональний комп'ютер HР6100 з програмним продуктом Catman Express 4.5. Аналогові виходи від датчиків прискорення підключалися до підсилювачів спектра сигналу, які в свою чергу були підключені до підсилювачаперетворювача SPIDER 8-FO5254. Датчик тиску безпосередньо було підключено до SPIDER 8-FO5254. Підсилювач-перетворювач SPIDER 8-FO5254 було з'єднано $з$ персональним комп'ютером НР6100. За допомогою програми Catman Express 4.5 отримані числові дані від підсилювачаперетворювача передавалися в пакети про- 
грами MS Excel для їхньої подальшої обробки (рис. 5).

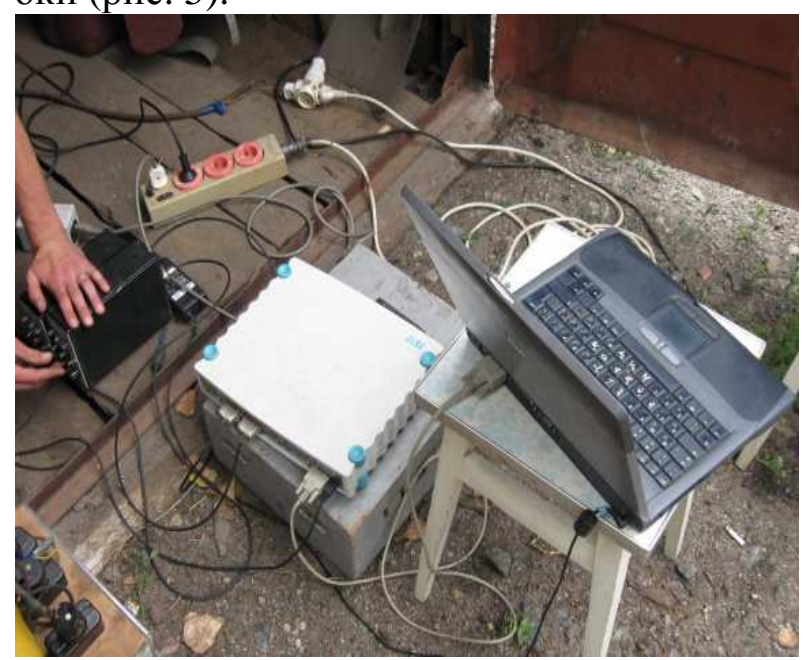

Рис. 5. Система збору даних

Датчики прискорення заводом виробником попередньо були таровані за власною спектральною характеристикою, що зазначено в їх технічному паспорті, де вказані їхні параметри налаштування та підключення (такі параметри налаштування датчиків виключають їхню похибку від власних частот коливань). Проте, перш ніж почати їх використання, вони були відкалібровані за величиною навантаження для їх синхронізації з підсилювачем-перетворювачем та визначена їхня тарувальна характеристика. Для калібрування акселерометрів застосовувався еталонний вібростенд, яким створювали вібрацію 3 прискорення 1g; $1,5 \mathrm{~g}, 2 \mathrm{~g}\left(\mathrm{~g}=9,8 \mathrm{M} / \mathrm{c}^{2}\right)$. До вібростенда приєднувався датчик прискорення, який сприймав дану вібрацію. У свою чергу, датчик прискорення через підсилювач спектра сигналу із налаштованими вхідними параметрами відповідного акселерометра, було приєднано до підсилювача-перетворювача, яким фіксувалися показники, що передавалися на персональний комп'ютер. При проведенні досліджень використовуються одночасно два датчики прискорення, а тому калібрування проводилося для кожного із них окремо, враховуючи їх різні тарувальні характеристики.

За величинами середніх значень калібрувальних параметрів були побудовані тарувальні характеристики акселерометрів (рис.6).
Функції апроксимації, побудовані для представлених на рис.6 графіків будуть виражатися наступними залежностями:

- для акселерометра №899146:

$$
x_{2 T}=4166,7 \times \mathrm{y}_{1 T},
$$

- для акселерометра №899150:

$$
x_{3 T}=-24525 \times \mathrm{y}_{2 T} \text {. }
$$


Рис. 6. Тарувальні характеристики акселерометрів

Для проведення тарування датчика тиску було використано еталонний манометр, який разом із датчиком був встановлений в напірній порожнині привідного гідроциліндра стрілової системи експериментальної установки крана-маніпулятора. Навантажуючи його стрілу вантажами в неробочому стані, манометром фіксувався тиск в гідросистемі та визначалася величина сигналу на датчику. На рис. 7 побудовано тарувальну характеристику датчиків тиску. 


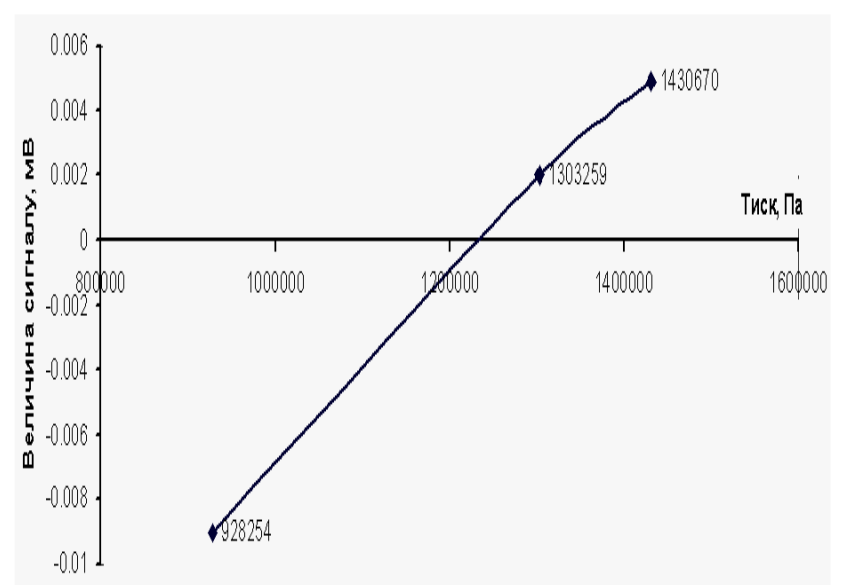

Рис. 7 Тарувальна характеристика датчика тиску

Функція регресії для апроксимованих даних датчика тиску буде:
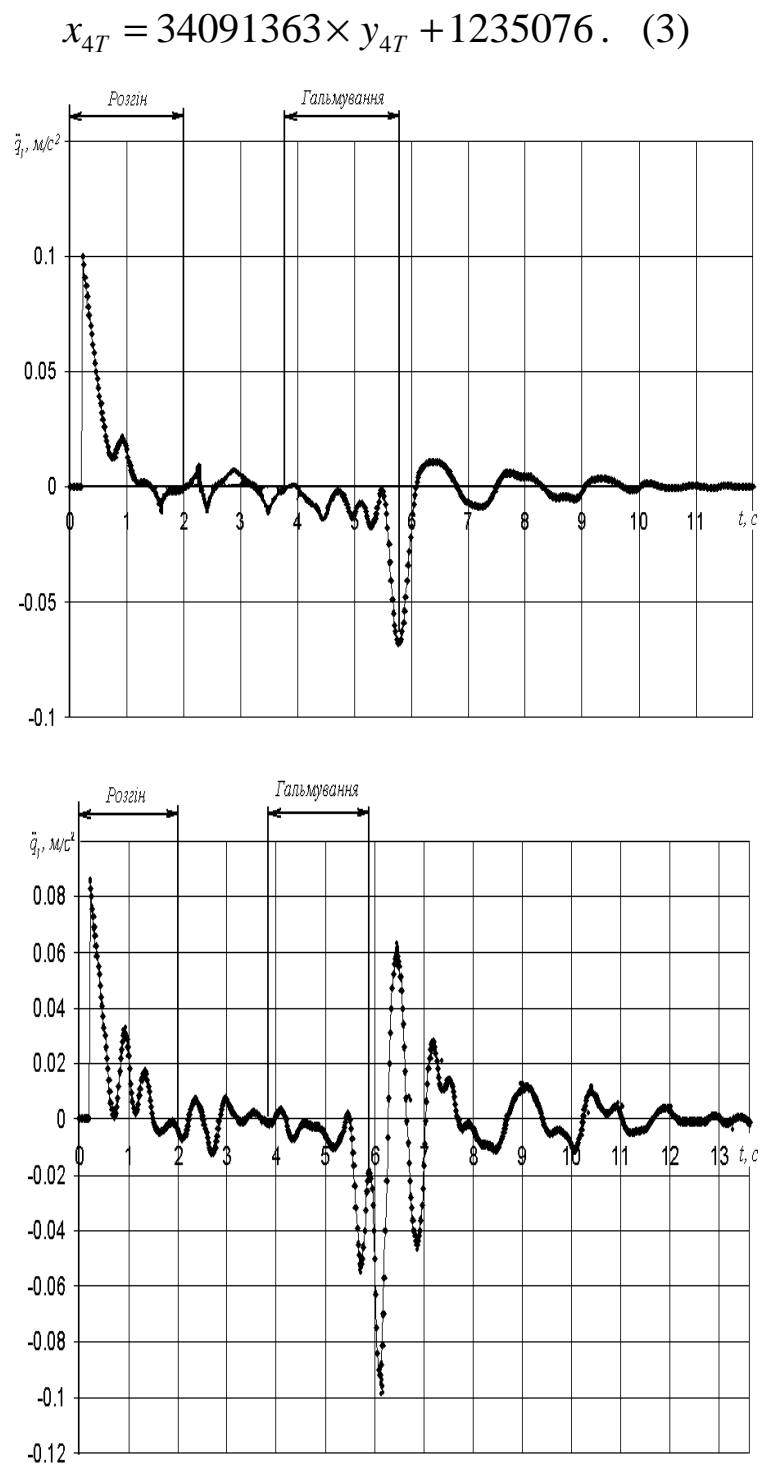

$a$
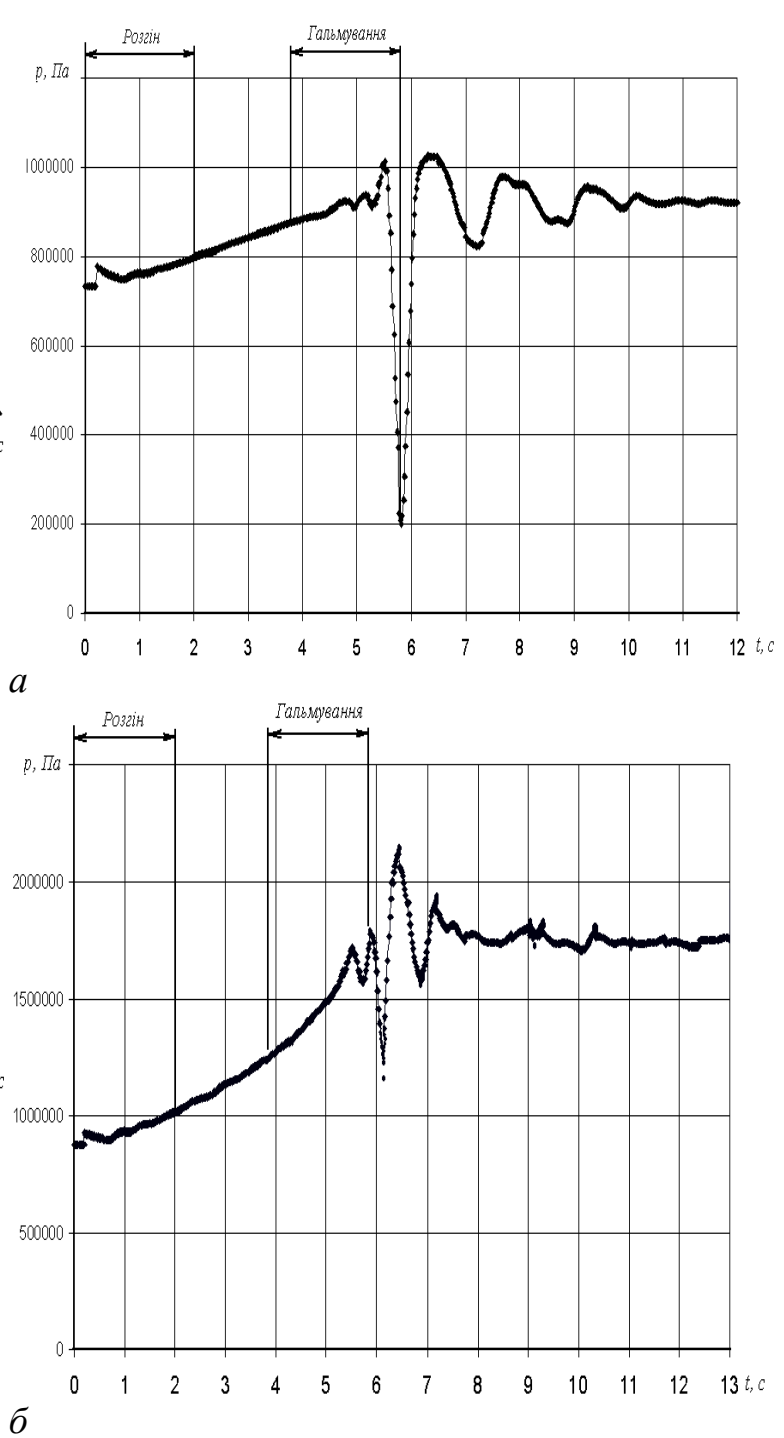

Рис. 8. Результати експериментальних досліджень динаміки роботи експериментальної установки крана-маніпулятора за неоптимального режиму руху гідроциліндра підйому стріли: $a$ - без вантажу; $\sigma$ - з вантажем 9,2кг
Вимірювання при експериментальних дослідженнях проводилися за роботи експериментальної установки кранаманіпулятора без навантаження та 3 навантаженням робочого обладнання.

Неоптимальне керування здійснювалося через стандартний розподільник бортової системи гідроприводу експериментальної установки крана-маніпулятора, а оптимальне - через секцію бортового гідророзподільника, яка була конструктивно змінена.

Результати вимірювань прискорення штока гідроциліндра підйому стріли та тиску робочої рідини у його напірній порожнині під час роботи експериментальної установки крана-маніпулятора в режимі підйому стріли подані на рис. 8, 9. 



Рис. 9. Результати експериментальних досліджень динаміки роботи експериментальної установки крана-маніпулятора за оптимального режиму руху гідроциліндра підйому стріли: $a$ - без вантажу; $\sigma$ - з вантажем 9,2кг

\section{Аналіз отриманих графіків}

За неоптимального режиму руху в початок пуску стрілової системи кранаманіпулятора на штоку гідроциліндра підйому стріли виникають значні динамічні навантаження, що є наслідком миттєвого зростання його прискорення. 3 графіків прискорення (рис. 8) видно, що стрімке підвищення прискорення штока гідроциліндра підйому стріли експериментальної установки крана-маніпулятора на початку пуску призводить до коливань стрілової системи, які передаються на привідну ланку та продовжуються протягом сталого руху та гальмування. Гальмування штока гідроциліндра підйому стріли експериментальної установки крана-маніпулятора за неоптимального режиму руху також відбува- ється за підвищених динамічних навантажень, які по завершенню переміщення стрілової системи перетворюються в залишкові коливання ії металоконструкції.

Модулі максимальних прискорень штока підйомного гідроциліндра за період пуску складають $0,08 \ldots 0,1 \mathrm{M} / \mathrm{c}^{2}$, а за період гальмування $-0,07 \ldots 0,11 \mathrm{~m} / \mathrm{c}^{2}$.

При гальмуванні експериментальної установки крана-маніпулятора відбувається також перепад тиску в його напірній порожнині, що видно 3 отриманих графічних залежностей, а це означає, що на його елементи діють змінні динамічні навантаження. Все це знижує надійність та ресурс крана-маніпулятора.

Дослідження роботи експериментальної установки крана-маніпулятора за оптимальним режимом роботи гідроциліндра під- 
йому стріли, показали, що в періоди його пуску та гальмування також виникають динамічні навантаження, проте вони значно менші, так як прискорення привідної ланки змінюється плавно - від нульового значення до свого максимуму і від максимуму до мінімуму. 3 графіків прискорення (рис. 9) видно, що за роботи експериментальної установки крана-маніпулятора на оптимальних режимах руху, мінімізуються та зникають коливання їі металоконструкції під час руху та по його завершенню. Модулі максимальних прискорень штока підйомного гідроциліндра за оптимального режиму його руху в період пуску складають $0,045 \ldots 0,08 \mathrm{M} / \mathrm{c}^{2}$, а в період гальмування $0,05 \ldots 0,053 \mathrm{M} / \mathrm{c}^{2}$.

Отже, окрім того, що прискорення привідної координати стрілової системи кранаманіпулятора за оптимальним режимом руху змінюється плавно, воно ще має менші максимальні значення за модулем. Зниження динамічних прискорень у процентному відношенні складає 20...51\%.

\section{Висновки}

Визначені результати експериментальних досліджень експериментальної установки крана-маніпулятора, показали виникнення під час його роботи динамічних прискорень та сил на привідній ланці. За неоптимальних режимів роботи стрілової системи експериментальної установки кранаманіпулятора такі динамічні характеристики руху набувають значних величин та створюють коливання в його робочому обладнанні.

Керуючи потоком робочої рідини за допомогою золотникового розподільника створюються оптимальні режими руху стрілової системи експериментальної установки крана-маніпулятора. За оптимальних режимів руху експериментальної установки крана-маніпулятора зменшуються динамічні навантаження та коливання в його стріловій системі та гідроприводі.

Проведені дослідження показали, що використовуючи дросельні проточки на робочих поверхнях золотника-розподільника керування крана-маніпулятора за його ро- боти , можна зменшити величини динамічних прискорень на 20...51\% та скоротити час залишкових коливань металоконструкції стріли та вантажу на 50\%.

\section{Література}

1. Волков Д.П., Николаев С.Н. Надежность строительных машин и оборудования. - М.: Высшая школа. 1979. - 400с.

2. Алексеева T.B. Гидропривод и гидроавтоматика землеройно-транспортных машин. Машиностроение. 1966. - 148.

3. Попов Д.А. Динамика и регулирование гидро- и пневмосистем, - М.: Машиностроение. 1977. - 423c.

4. Блюмин С.В. Гидропривод в механизмах подъема-опускания строительных и дорожных машин. - Строительные и дорожные машины, №1. - 1974. - С.15-16.

5. Смирнов О.А., Савельев В.П. Определение времени полного перемещения золотников распределителей с сервоуправлением. Строительные и дорожные машины, №7. 1984. C. 20-21.

6. Григоров О.В., Ловейкін В.С. Оптимальне керування рухом механізмів вантажопідйомних машин. Київ. 1997. - 262с.

7. Ловейкін В.С., Міщук Д.О. Визначення оптимальних режимів руху маніпулятора за процес пуску (гальмування) під час роботи за однієї з узагальнених координат. - Гірничі, будівельні, дорожні та меліоративні машини. №73. - 2009. - С. 35-42.

8. Ловейкін В.С., Мімук Д.О. Оптимізація режиму пуску висувної рукояті кранаманіпулятора під час горизонтального переміщення вантажу з урахуванням його коливань. - Гірничі, будівельні, дорожні та меліоративні машини. №73. - 2010. - С. 3-8.

9. Ловейкін В.С., Горбатюк С.В., Мімук Д.О. Синтез фізичної моделі крана-маніпулятора 3 гідроприводом на транспортному засобі. Сучасні інформаційні та інноваційні технології на транспорті. - 2011. - С. 147-154.

Рецензент: В.Б.Яковенко, д.т.н. проф. (КНУБА, Київ)

Отримано: 21.11.2011 p. 